УДК 005.001.8(075.8)

Ситник Н.I.

канд. біол. наук, доцент

Національний технічний університет Украӥни «КПI»

\title{
КОНЦЕПТУАЛЬНІ ЗАСАДИ МЕНЕДЖМЕНТУ ІДЕЙ В СУЧАСНИХ ОРГАНІЗАЦІЯХ
}

\section{КОНЦЕПТУАЛЬНЫЕ ОСНОВЫ МЕНЕДЖМЕНТА ИДЕЙ В СОВРЕМЕННЫХ ОРГАНИЗАЦИЯХ}

\section{CONCEPTUAL APPROACH TO IDEA MANAGEMENT IN MODERN ORGANIZATIONS}

Стаття присвячена дослідженню концептуальних засад формування системи менеджменту ідей в організації, яка забезпечує збільшення потоку нового знання у вигляді нових продуктивних ідей для розроблення інновачійних продуктів. Досліджений сучасний стан наукової літератури за даним напрямком. Пропонується розглядати менеджмент ідей як підсистему інноваційного менеджменту $і$ водночас підсистему управління знаннями. На основі дослідження етапу генерування знань в життєвому циклі знань запропонована конщептуальна схема менеджменту ідей. Управлінські рішення, щз становлять сутність менеджменту ідей, включають залучення відповідних ресурсів (людських, інформачійно-знаннєвих та часових), розвиток знаннєвих мереж, проведення комунікативних заходів, інтенсивне використання методів активізачіі творчого мислення та мотивачію до генерування ідей. Сформульовано поняття про знаннєві мережі як організачійної основи менеджменту ідей $і$ виявлена їх структура. Показано, що розвинуті організаційні знаннєві мережі мають інтегрувати традиџійні формально створені підрозділи з інноваційної діяльності, а також внутрішньо- $i$ зовнішньоорганізаційні знаннєві мережі.

Ключові слова: менеджмент ідей, генерування ідей, знаннєві мережі

Статья посвящена исследованию концептуальных основ формирования системы менеджмента идей в организации, обеспечивающей увеличение потока новых знаний в виде новых продуктивных идей для разработки инновационных продуктов. Изучено современное состояние научной литературы по теме исследования. Менеджмент идей рассматривается как подсистема инновачионного менеджмента и одновременно как подсистема управления знаниями. На основе изучения этапа генерирования знаний в жизненном ичикле знаний предложена концептуальная схема менеджмента идей. Управленческие решения, которые составляют сущность менеджмента идей, включают: привлечение соответствуюших ресурсов (человеческих, информационных и временных), развитие сетей знания, проведение коммуникативных мероприятий, интенсивное использование методов активизации творческого мылиления и мотивацию к генерированию идей. Сформулировано понятие о сетях знания как организационной основе менеджмента идей и выявлена их структура. Показано, что развитые организационные сети знания должны 
интегрировать традиционные формальные подразделения инновационной деятельности, а так же внутренние и внешние сети знаний.

Ключевые слова: менеджмент идей, генерирование идей, сети знаний

The article is devoted to investigation of basic concepts for idea management systems in modern organizations. Such systems are aimed at increasing a flow of new knowledge (new ideas) with a potential to be developed into innovations. The current state of scientific literature on the issue is analysed. Idea management is considered as a subsystem of innovation management and subsystem of knowledge management. Conceptual scheme of idea management is derived from the thorough study of idea generation stage in the knowledge life cycle. Management decisions related to idea management include mobilization of relevant resources (human, informational and time resources), development of knowledge networks, corporate events for knowledge exchange, enhancing tools for problem solving and motivation. The essence of knowledge networks and their structure are studied. It is shown that well established corporate knowledge networks should integrate traditional innovation units, as well as internal and external knowledge networks.

Key words: idea management, idea generation, knowledge networks

Вступ. Концепція інновацій відіграє важливу роль в економіці глобалізованого світу, де організації заради власного процвітання повинні навчитися перетворювати загрози на можливості, щоб протистояти ринковій турбулентності, економічним спадам і жорсткій конкуренції. Сучасні компанії все в більшій мірі бачать додаткову цінність в інвестуванні часу і зусиль у розвиток структур, систем і процедур, що забезпечують постійний потік інновацій. Відповідно інновації виступають як процес, яким потрібно управляти, i забезпечення ефективного управління цим процесом стає ключовим викликом для організацій.

Відправною точкою інновацій є генерування нових ідей. Інновації можуть розглядатися як ідеї, що були розвинені і впроваджені. Оскільки всі інновації мають своїм джерелом ідеї, то, очевидно, для забезпечення інноваційного розвитку компаніям необхідно налагодити постійне надходження нових ідей, щоб розширити можливості відбору найбільш перспективних для подальшого використання. Хоча організації зазвичай усвідомлюють необхідність розвитку систем виявлення, відбору, та оцінки цінної інформації з широкого кола сигналів бізнес-середовища, лише незначна їх частина ставить перед собою задачу управління процесом генерування ідей на організаційному рівні. Водночас, в стратегічному вимірі налагодження ефективного процесу генерування ідей створює потенційні переваги, які важко переоцінити. Це робить дослідження в даному напрямку актуальними як в теоретичному, так і в практичному плані.

Наукова література, присвячена аналізу генерування ідей в контексті інновацій, креативності та життєвого циклу знань досить численна i багатоаспектна. Грунтовні дослідження за цим напрямом були проведені T. 
Амабайл, Дж. Харрінгтоном, Т. Давенпортом, К.М. Віігом, П. Хейцигом, Р.Купером, К. Далькіром та ін. Разом 3 тим, концептуальні основи менеджменту ідей в сучасних організаціях розроблені недостатньо, що робить актуальним дане дослідження.

Постановка завдання. Дослідження присвячене організаційним аспектам генерування ідей в сучасних організаціях i спрямоване на вирішення таких завдань: проаналізувати існуючі теоретичні уявлення щодо сутності етапу генерування ідей в життєвому циклі знань; дослідити історію розвитку поняття «менеджмент ідей» і конкретизувати його сутність; встановити структурні елементи загальної схеми менеджменту ідей в організації; визначити структуру знаннєвих мереж та їх роль у генеруванні ідей.

Методологія дослідження. Теоретико-методологічну основу дослідження складають праці провідних науковців, присвячені генеруванню ідей. При проведенні дослідження використовувалися загальнонаукові методи: конкретизації (для дослідження історичних аспектів менеджменту ідей), систематизації, порівняння і узагальнення (для дослідження існуючих теоретичних уявлень щодо сутності менеджменту знань і моделей життєвого циклу знань), аналізу і синтезу (для розроблення авторської схеми менеджменту знань та мережі організаційних структур з генерування ідей).

Результати дослідження. Історично перші спроби цілеспрямованого управління ідеями відносяться до початку 70 -х років минулого сторіччя, коли для координації креативних зусиль працівників компанії почали використовувати скриньки для збору ідей і пропозицій. Цей захід, який можна вважати прототипом системи менеджменту ідей, став основою руху за постійне удосконалення. Його мета полягала у широкому залученні професійних знань i творчої ініціативи кожного працюючого для досягнення адаптивних, як правило, незначних покращень виробничого процесу. Фактично рух за постійне вдосконалення в більшій мірі був спрямований на заохочення працівників до участі в житті організації та формування позитивного ставлення до змін, ніж на отримання реальних результатів у вигляді інноваційних ідей, які б мали істотний позитивний вплив на діяльність компанії.

На сьогодні поняття «менеджмент ідей» в основному асоціюється 3 сучасним програмним забезпеченням, яке створює IT-платформи, призначені для збору, оцінки та відбору найкращих ідей 3 високим потенціалом щодо їх подальшого використання в інноваційній діяльності. Інформаційні системи менеджменту ідей поєднують два елементи інструменти різностороннього співробітництва і процеси руху ідей між учасниками. Хоча в порівнянні зі збором ідей на паперових носіях 
комп'ютеризований підхід забезпечує приріст як числа залучених учасників, так і якості ідей, однак концептуально продовжує бути досить обмеженим, залишаючи поза увагою інші важливі організаційні аспекти, що впливають на процес генерування ідей. Взагалі, для багатьох компаній управління ідеями все ще означає лише впровадження технологічних рішень для автоматизації соціальних комунікацій, тоді як роль організаційних рішень недоццінюється.

Представляється, що поняття менеджменту ідей потребує більш широкого трактування 3 урахуванням таких міркувань, що визначають його роль і зміст:

-3 одного боку, генерування ідей $\epsilon$ невід'ємною частиною, початковим етапом інноваційного процесу і повинне розглядатися в контексті реалізації інноваційної стратегії організації, а з іншого - генерування ідей $є$ невід'ємною частиною життєвого циклу знань і повинно розглядатися в контексті системи менеджменту знань;

-менеджмент ідей є структурованим багатокомпонентним процесом, окремі компоненти якого в сукупності забезпечують очікуваний результат у вигляді збільшення числа продуктивних ідей, що можуть бути реалізовані в інноваційних продуктах.

Отже, менеджмент ідей можна визначити як підсистему інноваційного менеджменту і водночас підсистему управління знаннями, що являє собою сукупність взаємопов'язаних управлінських рішень структур, процедур, практичних інструментів та ресурсів, - які у взаємодії забезпечують збільшення потоку нового знання у вигляді нових продуктивних ідей з метою розроблення інновацій.

Згідно з сучасними уявленнями інноваційний процес включає чотири етапи: пошук, відбір, впровадження і схвачування [1]. На етапі пошуку визначаються можливості для інновацій шляхом генерування максимальної кількості ідей. Масив ідей, отриманих на етапі пошуку, підлягає експертній оцінці й селекції на етапі відбору, щоб найкращі 3 них були використані у вигляді інновацій на етапі впровадження. На етапі схвачування результати інноваційної діяльності оцінюються за сукупністю отриманих переваг, зокрема, їх сприйняттям споживачами і отриманим економічним результатом, щоб знову виявити потенційні потреби у нових ідеях. Генерування ідей $є$ початковим етапом інноваційного процесу, i його результат в значній мірі визначає успішність наступних етапів щодо обсягу задіяних ресурсів, швидкості реалізації інноваційного проекту, доданої вартості та ринкового потенціалу нового продукту.

3 іншого боку, генерування ідей $є$ частиною більш загального процесу управління знаннями, яке в добу економіки знань перетворюється на стратегічний імператив. Управління знаннями складається iз 
систематичних процесів отримання, організації, підтримки, використання, обміну і відтворення всіх форм знання з метою покращення організаційної результативності та створення додаткової цінності. Починаючи з роботи [2], зусилля дослідників в цьому напрямі були спрямовані на створення численних моделей управління знаннями, як послідовних, так і циклічних. Вони 3 різним ступенем інтегрованості відображають етапи життєвого циклу знань і відповідні їм організаційні інструменти управління знаннями. Згідно з поширеною моделлю, що була запропонована в рамках Європейської Концепції по управлінню знаннями, життєвий цикл знань включає п'ять етапів: ідентифікація, створення, зберігання, розповсюдження і використання знань [3]. В моделі підкреслюється роль життєвого циклу знань в забезпеченні підтримки бізнес-процесів організації, маючи на увазі і всіх його зовнішніх учасників: споживачів продукції і послуг, клієнтів, партнерів. Водночас, тісна взаємодія з ними через бізнес-мережі розглядається як необхідна умова для ідентифікації існуючих знань, визначення потреб у новому знанні та їх створення.

У всіх відомих моделях управління знаннями як один з початкових етапів виділяється етап генерування нових знань (ідей), хоча різні автори використовують дещо відмінну термінологію для його позначення: побудова знань [2], отримання знань [4], генерування знань [5], створення знань $[3,6]$. Якщо в одних моделях $[3,5,6]$ етапи ідентифікації й створення нових знань диференціюються, то в моделі [2] вони інтегровані в один. В даному дослідженні, враховуючи схожість організаційних заходів з управління ідентифікацією і генеруванням знань, представляється доцільним теж розглядати їх об'єднано.

На етапі генерування знань (ідей) первинним є ідентифікація потреби в знаннях для конкретної предметної області й конкретного виду діяльності. Ідентифікація передбачає аналіз стратегічних цілей у виробництві конкурентоздатних товарів і послуг та виявлення знань, необхідних для досягнення цих цілей [3]. Якщо говорити про головні когнітивні процеси, в які залучені працівники компанії на етапі генерування знань, то вони включають отримання, аналіз, синтез, реконструкцію, кодифікування й організацію знань. Отримання знань відбувається за допомогою різноманітних засобів, таких як особистий досвід, освіта, професійне навчання, спілкування з колегами, наставниками тощо. Аналіз знань включає встановлення змісту і цінності шляхом абстрагування, ідентифікації трендів розвитку, встановлення причиннонаслідкових зв'язків, усунення протиріч і перевірку валідності знань. По суті, на етапі генерування знань відбувається активне навчання учасників, оскільки передбачається не просто засвоєння масиву інформації, а й іiі активне переосмислення та трансформація з урахуванням суб'єктивно 
сприйнятих стратегічних потреб компанії. Види діяльності, пов'язані 3 цією фазою, включають проведення маркетингових досліджень, документування проблемних питань, аналіз існуючої практики тощо $[2,6]$.

Специфіка видів діяльності, що відбуваються на етапі генерування ідей та відповідних їм когнітивних процесів, зумовлюють особливості формування системи менеджменту ідей. Загальна схема менеджменту ідей представлена на рис. 1.

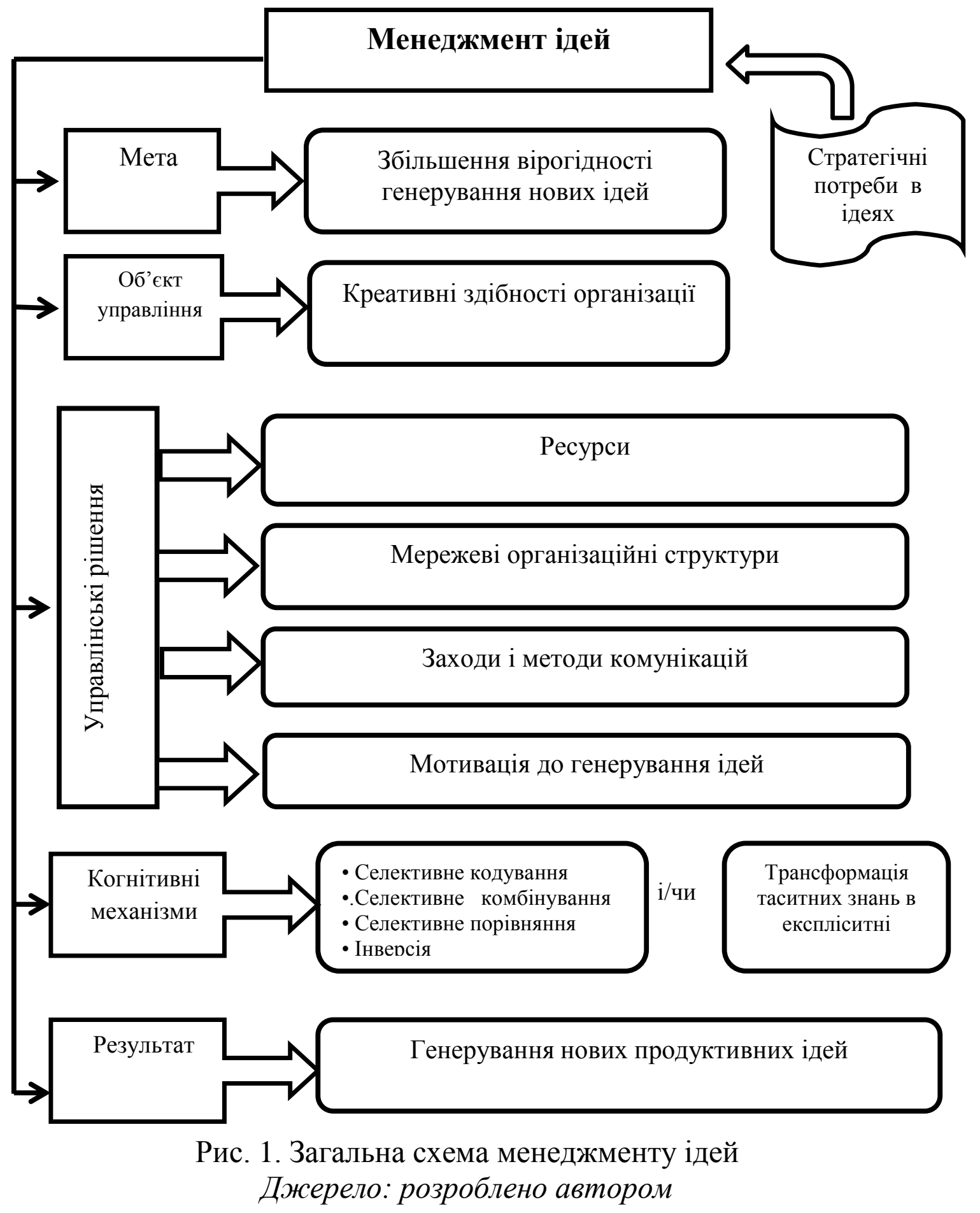


Менеджмент ідей підпорядкований стратегічним потребам організації в інноваційних продуктах, що дозволяе вже на перших етапах задати магістральний напрям пошуку, спрямувати креативні зусилля персоналу на вирішення важливих для організації задач й уникнути розпорошення ресурсів, які завжди обмежені. 3 іншого боку, недопустимою $є$ і занадто жорстка регламентація, оскільки вона звужує простір для творчого пошуку i тому може мати негативний вплив на ступінь новизни і якість отриманих ідей.

Управлінські рішення, що становлять сутність менеджменту ідей, відносяться до однієї з чотирьох груп: надання ресурсів, створення i підтримка діяльності організаційних структур, спрямованих на генерування ідей, використання специфічних заходів і методів комунікації, а також мотивація до генерування ідей (див. рис. 1).

Порівняно 3 наступними етапами життєвого циклу знань, особливо впровадженням, генерування ідей не вимагає значних фінансових витрат. Задіяні при цьому ресурси - людські, інформаційно-знаннєві та часові, можуть бути виділені, якщо менеджмент готовий активно підтримувати i заохочувати творчу ініціативу персоналу організації.

Теоретичною основою створення організаційних структур, що забезпечують генерування ідей, $є$ теорія колективного пізнання (distributed cognition) Е. Хатчінса [7]. Згідно з уявленнями Е. Хатчінса нові ідеї з'являються не самі по собі, а будуються на ідеях інших людей шляхом формування нових знаннєвих структур в результаті тісної співпраці та взаємодії у складних соціальних системах. Учасники групи роблять свої інтелектуальні внески у спільну справу, і окремі індивідуальні частини інтегруються разом, щоб створити нове знання. Спільне використання інтелектуальних ресурсів розширює когнітивні можливості учасників групи настільки, що вони здатні вирішувати завдання, які б при автономній роботі були для них нездійсненними.

Традиційно генерування нових ідей пов'язують 3 діяльністю підрозділів НДДКР, проектних, кросфункціональних, експертних груп та аналогічних формальних структур, що спеціально створюються для виконання прикладних НДР, проектування складних об'єктів, процесів i систем і вирішення складних неструктурованих проблем. Однак, згідно 3 теорією колективного пізнання творчий потенціал організації значно розширюється, якщо, не обмежуючись колом традиційних формальних структур, організації залучають до генерування ідей інші джерела, як в межах організації, так і поза нею. Підкреслюється, що генерування ідей зараз стає бізнес-функцією чи діяльністю, що вимагає залучення в бізнес кожного працівника, і навіть тих, хто не належить до організації, однак пов'язаний з нею. 
Важливою складовою внутрішніх знаннєвих мереж, окрім традиційних організаційних структур, стають окремі працівники, які за власною ініціативою висувають нові ідеї, що з часом можуть стати основою нових інноваційних проектів (внутрішнє підприємництво). Організація підтримує внутрішнє підприємництво, забезпечуючи доступ до джерел різноманітної інформації та час, вільний від виконання рутинних обов'язків. Невипадково в багатьох інтелектуальних організаціях $10-20 \%$ робочого часу працівники можуть використовувати на власний розсуд.

Іншою складовою внутрішніх знаннєвих мереж $\epsilon$ неформальні об'єднання працівників за спільними професійними інтересами, які називаються співтовариствами практиків (communities of practice). Завдяки інтенсивним комунікаціям, усуспільненню досвіду, обміну знаннями та взаємодії співтовариства практиків створюють потужну основу для організаційного навчання та виникнення нового знання [8].

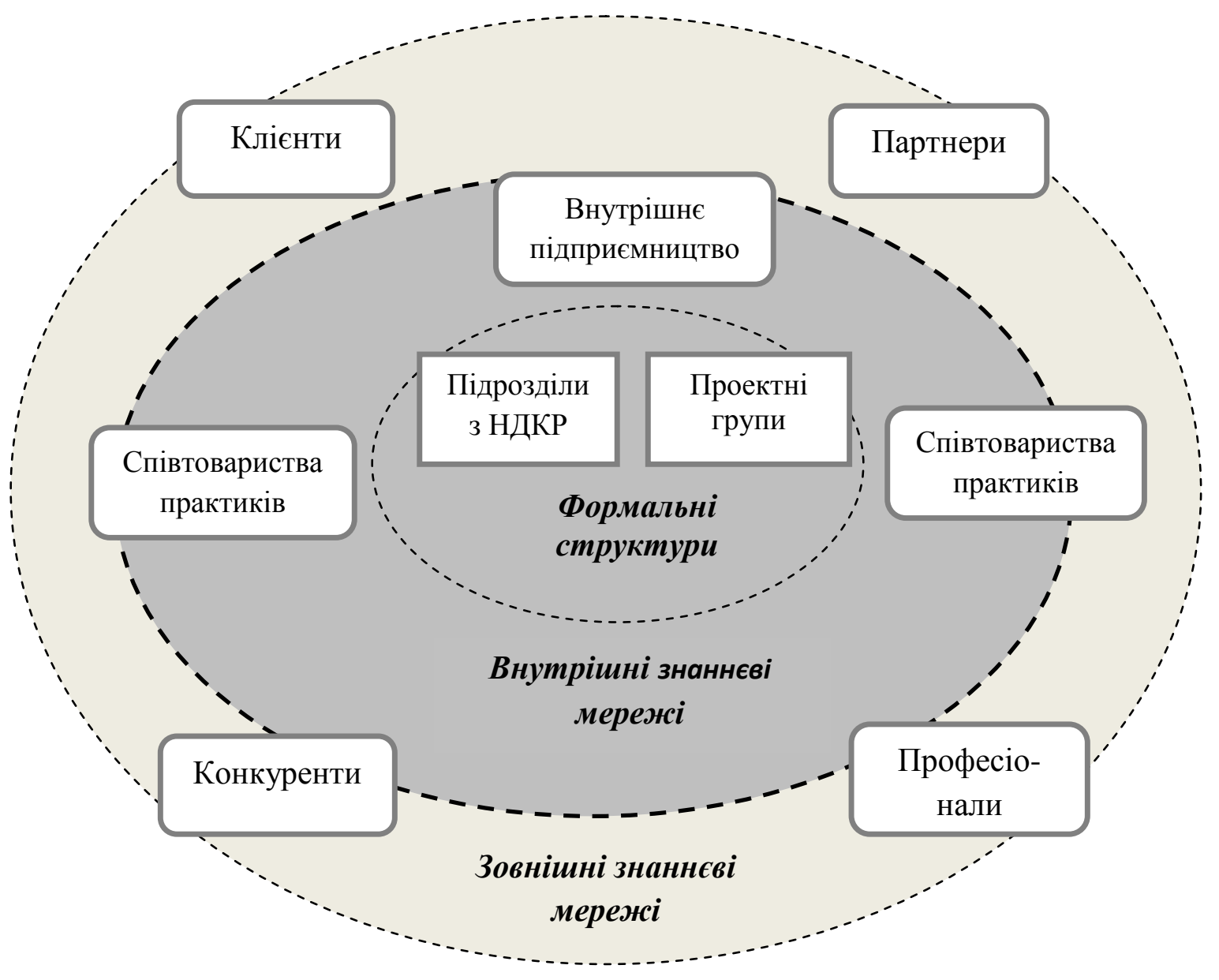

Рис. 2. Мережа організаційних структур з генерування ідей Джерело: розроблено автором 
В сукупності формальні та неформальні організаційні структури, що забезпечують генерування ідей в сучасних організаціях, створюють розгалужену внутрішню знаннєву мережу з високим творчим потенціалом (Рис. 2).

Творчі можливості організації ще більше розширюються, якщо їй вдається долучити до рішення своїх завдань зацікавлених осіб поза межами організації (клієнтів, партнерів, постачальників, конкурентів та окремих осіб), створивши зовнішню знаннєву мережу, що підживлює внутрішню своїми знаннями і досвідом. Розвиток зовнішніх знаннєвих мереж забезпечується на основі нової бізнес-моделі, що отримала назву «краудсорсинг». Краудсорсингом називається практика отримання необхідних ідей, послуг або контенту через звертання про допомогу, спрямоване до великої кількості людей, головним чином онлайнової спільноти» [9]. Масове використання Інтернету та соціальних мереж створює необхідну технологічну базу для налагодження ефективної координації та взаємодії осіб i груп. Прикладами програмного забезпечення для створення знаннєвих мереж і максимального залучення різноманітних джерел генерування ідей $є$ IdeasMine, Crowdicity, OrganisedFeedback, Exago Innovation та інші.

Зрозуміло, що можливості впливу організації на зовнішні знаннєві мережі обмежені, головним чином, створенням он-лайнових платформ для комунікацій, тоді як арсенал заходів, спрямованих на активізацію внутрішніх мереж, досить великий. Серед комунікаційних заходів, що сприяють генеруванню ідей внутрішніми знаннєвими мережами, слід відзначити проведення інноваційних семінарів, он-лайнових сесій, використання технологічних дорожніх карт (графічних інструментів для координації та планування майбутніх технологічних рішень), корпоративне підприємництво (пошукові дослідження за власною ініціативою працівників за підтримки менеджменту).

Менеджмент ідей передбачає також управління груповою динамікою для активізації творчого мислення. Мається на увазі, в першу чергу, координація та фасилітація групових дискусій, використання методів активізації творчого мислення. Останні асоціюються 3 добре відомим мозковим штурмом, хоча не обмежуються ним. Для ідентифікації та визначення можливостей застосовуються техніки «Чому?», спостереження за основними чи продвинутими користувачами, карти проблем, когнітивні карти, послідовні узагальнення, рефрейминг, діаграми причиннонаслідкових зв'язків, тощо. Генерування ідей стимулюється різними видами мозкового штурму, гірлянд випадковостей i асоціацій, шести капелюхів, творчою візуалізацією, контрольних списків (список «SCAMPER», контрольний список удосконалення продукту), синектикою, 
інноваційною грою, морфологічним аналізом, вартісно-функціональним аналізом, тощо.

В кожному конкретному випадку методи активізації творчого мислення повинні добиратися 3 урахуванням специфіки поставленого завдання, попереднього досвіду, комунікативних компетенцій учасників та ситуативних чинників. При цьому більшість з них розраховані на особисте, а не он-лайнове спілкування.

Методи стимулювання творчої активності персоналу організації можна розділити на дві групи - прямого і опосередкованого стимулювання [10].

До методів прямого стимулювання відносяться: гранти на виконання пошукових робіт, одноразові премії, розмір яких залежить від додаткового прибутку, отриманого організацією від впровадження ідеї за певний період, гарантоване кар'єрне зростання або підвищення заробітної плати. До методів опосередкованого стимулювання відносяться: самостійність у виборі тематики пошукових досліджень, самостійність у формуванні робочої групи, плануванні іiі діяльності і розподілі ресурсів, зміна особистого статусу або статусу очолюваної робочої групи, корпоративні моральні заохочення і визнання заслуг [10].

Учасники зовнішніх знаннєвих мереж долучаються до генерування ідей не 3 розрахунку на фінансову винагороду, а керуючись альтруїстичними міркуваннями, бажанням зміцнити свої зв'язки 3 організацією, отримати визнання інших фахівців, підняти свій авторитет в професійних колах, отримати зворотний зв'язок від фахівців, пізнавальним інтересом чи можливістю побачити свої ідеї втіленими у життя.

В сукупності розглянуті вище управлінські рішення запускають когнітивні механізми генерування ідей. На даний час питання, яким саме чином виникають нові ідеї, залишається дискусійним. У найбільш загальному сенсі виникнення нових ідей можна пояснити як результат створення нових взаємозв'язків у вже існуючих знаннях. Дж. Девідсон основними механізмами генерування ідей вважає такі: 1) селективне (вибіркове) кодування, тобто розуміння того, що з наявної інформації має вирішальне значення для вирішення проблемного питання; 2) селективне комбінування, тобто розуміння того, які фрагменти інформації й як потрібно з'єднати для отримання правильного рішення; 3) селективне порівняння, тобто поєднання інформації про поточну проблему з певною інформацією про інші проблеми, або рішення за аналогією [11]. Альтернативним поясненням механізму генерування ідей $є$ трансформація таситних (неявних) знань в експліцитні (явні) за циклом SECI. Завдяки дії когнітивного механізму генеруються нові ідеї, що стають основою 
інновацій, а отже забезпечують подальший розвиток компаній в довготривалій перспективі.

Висновки. Стаття присвячена дослідженню концептуальних засад формування системи менеджменту ідей в сучасних організаціях.

Наукова новизна та теоретичне значення проведеного дослідження полягають у такому.

Надане авторське формулювання поняття менеджменту ідей як підсистеми інноваційного менеджменту і водночас підсистеми управління знаннями, що являє собою сукупність взаємопов'язаних управлінських рішень - структур, процедур, практичних інструментів та ресурсів, - які у взаємодії забезпечують збільшення потоку нового знання у вигляді нових продуктивних ідей з метою розроблення інновацій.

На основі дослідження сутності етапу генерування знань в життєвому циклі знань запропонована концептуальна схема менеджменту ідей.

Сформульовано поняття про знаннєві мережі як організаційної основи менеджменту ідей і виявлена їх структура. Розвинуті знаннєві мережі включають: формально створені підрозділи 3 інноваційної діяльності, (підрозділи з НДКР, робочі, проектні, аналітичні групи і т.п.), внутрішні знаннєві мережі (співтовариства практиків, ініціативні групи), зовнішні знаннєві мережі (клієнти, партнери, постачальники, конкуренти та окремі зацікавлені особи).

Практичне значення даного дослідження полягає у формулюванні конкретних управлінських рішень, що мають результатом підвищення числа нових продуктивних ідей. Такі управлінські рішення стосуються залучення відповідних ресурсів (людських, інформаційно-знаннєвих та часових), розвиток знаннєвих мереж, проведення комунікативних заходів, інтенсивне використання методів активізації творчого мислення та створення мотивації до генерування ідей.

Перспективи подальших досліджень за даним напрямом полягають в науковому осмисленні кращого досвіду 3 менеджменту ідей, накопиченого світовими компаніями-лідерами, та конкретизації обмежень обміну знань $з$ огляду на захист інтелектуальної власності та економічну безпеку організації.

\section{Лiтература:}

1. Tidd J., Managing Innovation: Integrating Technological, Market And Organizational Change / J. Tidd, J. Bessant. $-4^{\text {th }}$ edition. - West Sussex: John Willey\&Sons Ltd. - 2009. $-602 p$.

2. Wiig K. M. Knowledge Management Foundations: Thinking About Thinking: How People And Organizations Create, Represent, And Use Knowledge / K. M. Wiig. Arlington, TX: Schema Press. - 1993. - 302 p. 
3. European Guide To Good Practice In Knowledge Management - Part 1: Knowledge Management Framework. - available at: ftp://cenftp1.cenorm.be/PUBLIC/CWAs/eEurope/KM/CWA14924-01-2004-Mar.pdf.

4. Meyer M. H. The Design And Development Of Information Products // M. H. Meyer, M. H. Zack / Sloan Management Review. - 1999. - Vol. 37. - P.43-59.

5. Heisig P. Harmonization Of Knowledge Management: Comparing 160 KM Frameworks Around The Globe // P. Heisig / Journal of Knowledge Management. -2009. - Vol. 13. No. 4. - P. 4-31.

6. Max Evans M. A Holistic View Of The Knowledge Life Cycle: The Knowledge Management Cycle (KMC) Model // M. Max Evans, K. Dalkir, C. Bidian/ Electronic Journal of Knowledge Management. - 2014. - Vol. 12. - Issue 2. - P.85-97. - available at: www.ejkm.com

7. Hutchins E. Cognition In The Wild / E. Hutchins. - Cambridge: MIT Press, 1995. - 443 p.

8. Wenger E. C. Communities Of Practice: The Organizational Frontier // E. C. Wenger, W. M. Snyder / Harvard Business Review. - 2000. - Jan.-Feb. - P. 139-145.

9. Словник Мерріам Вебстер. [Електронний ресурс]. - Режим доступу: http://www.merriam-webster.com/dictionary/crowdsourcing

10. Довгань Л.Є. Креативний менеджмент: навч. посібник / Л.Є. Довгань, Н.І. Ситник. - К.: ВД Вінниченко. - 2014. - 248 с.

11. Davidson J. E. The Role Of Insight In Giftedness / R.J. Sternberg and J.E. Davidson (eds). Conceptions of Giftedness. - NY: Cambridge University Press, 1986. - P. 201222. 